\section{SOUTH-EASTERN UNION OF SCIENTIFIC SOCIETIES}

\section{ANNUAL CONGRESS}

\footnotetext{
$\mathrm{T}$
} HE South-Eastern Union of Scientific Societies held its forty-eighth annual congress at Reading on July 24, a single day of sessions attended by eighty representatives and members, a number above average for such war-time congresses.

A representative assembly to transact the business of the constituent societies was held in the Abbey School, at which C. E. N. Bromehead of the Geological Survey was elected president of the Union for 1943-44. The new treasurer is Mr. Clifford Musgrave of the Brighton Museums.

"Geology and Health" was the title of Mr. Bromehead's address. His theme centred around the effect upon the nation's health of minute quantities of certain trace-elements which are only now beginning to be understood or even recognized. In particular he described his own work as a geologist together with medical research into cases of endemic fluorine poisoning. Since 1930, work in the United States and India has shown that as little as one or two parts per million of fluorine in drinking water has a serious effect on human teeth during the period of their formation, and Dr. D. C. Wilson, who has done much work on fluorosis in India, in 1939 found that 'mottled teeth' due to this cause are not uncommon in Great Britain. Water supplies are being examined for its contamination in collaboration with Dr. M. M. Murray, a biochemist. Fluorosis may attack all bony structures in adults as well as children and may produce curvature of the spine, arthritis, neuritis or any rheumatic symptoms and, possibly, goitre. At Hook Norton in Oxfordshire cases of fluorosis have been accompanied by cretinism even where deficiency of iodine is not known; its assimilation may be inhibited by fluorine. Another traceelement of importance is molybdenum, which only affects cattle and sheep-not horses and pigsthrough eating the pasture in fields where the soil contains appreciable quantities of that element ; the cure is doses of copper sulphate administered to the sickening animals. A plea was made for the closer collaboration of geologists and medical research workers in solving many problems of health in which a geological aspect is involved.

At the sectional sessions the following papers were read: "Manorial Pigeon Houses", by E. Yates; "The Future of Fossil Botany", by Prof. T. M. Harris; "The Future of Quaternary Research in Britain", by K. P. Oakley ; "The Recent History of the Rivers near Reading", by Prof. H. L. Hawkins; "A Survey of Malvern in Social Science", by Mrs. D. Farquharson; "Seeds and Seed Growing", by A. P. Balfour; "The Edible Crab", by E. A. Robins; "The Striped Hawk-moth in the British Isles, MayJune, 1943", by Capt. T. Dannreuther-the latter on behalf of the Insect Immigration Committee to report greater abundance this year than ever known since the records started in 1824, namely, 340 moths seen and 97 captured and another generation expected in the autumn bred here.

Later, visits were paid to the University of Reading, the Municipal Museum, the Abbey ruins, etc.

T. D.

\section{APPOINTMENTS VACANT}

APpLICATrons are invited for the following appointments on or before the dates mentioned :

Junior Scientific Assistant (MALE or Female) in AgriculturaI Economics-The Agricultural Officer, University of Bristol, 22 Berkeley Square, Bristol (August 25).

FIELDMAN (TEYPORARY) TO THE ADVISORY ENTOMOLOGICAL SECTION FIELDMAN (TEMPORARY) TO THE ADVISORY ENTOMOLOGICAL SECTION
of the Department of Agriculture-The Registrar, The University, of the Department
Leeds (August 26).

TEACHER OF CHEMISTRY for Junior work in Technical Day School and Industrial Intermediate B.Sc. class in the Technical College, an a TEACHER OF MATHEMATICS for Junior work in Technical Day Schoo and Technical and Intermediate B.Sc. Mathematics in the Technical College-The Chief Education Officer, Education Offices, Park Road, West Hartlepool (August 27)

AsSISTANT TO THE ADVISORY CHEMIST (should possess an Honour Degree in Science, with a knowledge of analytical work) - The Advisory Chemist, School of Agriculture, Cambridge (August 28).

Teachers (2) of Engineering SubJects, one of whom should be able to teach some Metallurgy, in the Smethwick Municipal CollegeThe Chief Education Officer, 215 High Street, Smethwick (August 30). LECTURER IN GEOLOGY-The Secretary, University of Durham, 38 North Bailey, Durham (August 30).

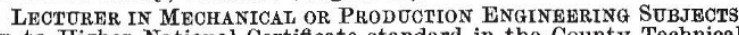
up to Higher National Certificate standard in the County Technica College, Wednesbury

IECTURERS IN MECHANICAI ENGINEERING, qualified to teach IECTURERS IN MECHANICAI ENGINEERING, qualified to teach
Strength of Materials and Metallurgy up to Higher National Certiflcate School of Art, Forest Road, Walthamstow, London, E.17 (August 31). PSYCHIATRIST (FULL-TIME OR PART-TIME), and a FULL-TIME EDUCATroNAL PSYCHOLOGIST, in the Liverpool Child Guidance Clinic-The Town Clerk and Clerk to the Local Education Authority, Town Hall, Liverpool (endorsed 'Child Guidance Clinic') (August 31).

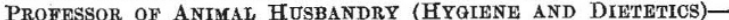
The Secretary, Royal (Dick) Veterinary College, Edinburgh (August 31).

Power Station SUPERINTENdent-The Engineer and Manager, Brighton Electricity Undertaking, Electric House, Castle Square, Brighton 1 (endorsed 'Power Station Superintendent') (August 31).

Demonstrator of BIOLOGY - The Dean, Guy's Hospital Medical School, Sherwood Park, Tunbridge Wells (September 1).

LECTURER IN THE DEPARTMENT OF DXEING in the Bradford Technical College-The Director of Education, Town Hall, Bradford (September 1).

LECTURER in Mathematios in the Coventry Technical CollegeThe Director of Education, Education Offices, Coventry (September 7). LABORATORY StewARD in the School of Pharmacy-The Registrar, University College, Nottingham.

Scinntifio EDITor of Proceedings, Bulletin, Reports AND PUBLICATIONS-The Secretary, British Coal Utilisation Research Association, Experimental Station, Rickett Street, London, S.W.6.

SENior TeChNical Advisers (3), (Reference No. C.1791), and JUNIOR TECHNICAL ADVISERS (2), (Reference No. C.1792), for general work in the Machine Tool Control Section of the Department of Supply of the Government of India-The Ministry of Labour and Nationa Service, Central (Technical and Scientific) Register (quoting the appropriate Reference No.), Alexandra House, Kingsway, London, W.C.2. LECTURER (TEMPORARY) IN THE DEPARTMENT OF ElECTRICAL
ENGINERRING-The Principal, Borough Polytechnic, Borough Road, London, S.E.1.

DEPUTY Governmext Chemist for Jamaica-The Ministry of Labour and National Service, Central (Technical and Scientiflc) Register (Reference No. O.N.F.1525), Alexandra House, Kingsway, London, W.C.2.

FUel EfFiciency Ofyider (TeChNidal) for the non-ferrous metals (wrought) industry-The Ministry of Labour and National Service, Central (Technical and Scientific) Register (Reference No, O.N.F' $1526 \mathrm{X})$, Alexandra House, Kingsway, London, W.C.2

Teachers for Evening Crasses in Physics up to Intermediate Science standard-The Director of Education, The Polytechnic, 309 Regent Street, London, W.1.

GEOGRAPHY MISTRESS for a Girls' Boarding College in NatalWducation Committee, Society for the Oversea Settlement of British

\section{REPORTS and other PUBLICATIONS}

\section{(not included in the monthly Books Supplomont)}

\section{Great Britain and Ireland}

British Rubber Producers' Research Association. Publication No. 33: The Vapour-Pressure Equations of Solutions and the Osmotic Pressure of Rubber. By A. R. Miller. Pp. 16. Publication No. 34: Characteristics of Wild Rubber. By G. R. Tristram, G. Gee, L. R. G. Treloar and G. A. Jeffrey. Pp. 4. Publication No. 35: Why is Rubber Treloar and G. A. Jeffrey. Pp. 4. Publication No. 35 : No. 36 : Interaction between Rubber and liquids, 4: Factors governing the Abaction between Rubber and liquids, 4: Factors (London: British Rorption of Oil by, Ruber. Ber Association.) 